\title{
IAMJ
}

INTERNATIONAL

AYURVEDIC

MEDICAL JOURNAL

Review Article

ISSN: 2320-5091

Impact Factor: 6.719

\section{CORRELATION BETWEEN PRAKRITI AND RITUCHARYA: A CONCEPTUAL STUDY}

\author{
Savita $^{1}$, Ashok Kumar Sharma ${ }^{2}$
}

${ }^{1}$ MD Scholar, P.G. Department of Kriya Sharir, MMM Govt. Ayurveda College, Udaipur, Rajasthan, India

${ }^{2}$ Proffesor \& HOD, P.G. Department of Kriya Sharir, MMM Govt. Ayurveda College, Udaipur, Rajasthan, India

Corresponding Author: $\underline{\text { savitasura05@gmail.com }}$

\section{https://doi.org/10.46607/iamj2709072021}

(Published Online: July 2021)

Open Access

(C) International Ayurvedic Medical Journal, India 2021

Article Received: 28/06//2021 - Peer Reviewed: 02/07/2021 - Accepted for Publication: 04/07/2021

\section{Check for updates}

\begin{abstract}
Ayurveda is the science of life, or the knowledge of living, which addresses all of the aspects of life that make it worthwhile to live in its purest form. The concept of Tridosha and Prakriti is central to Ayurveda's philosophy. Prakriti describes an individual's physical, physiological, and psychological expression. The unique biological constitution generated by the preponderance of the Tridoshas Vata, Pitta, and Kapha is known as human Prakriti. Such characteristics are inherited and remain with a person throughout his or her life. Prakriti is a person's constitution, which is unique to them and is regulated by their physiology. Individuals with Vata Prakriti have Alpa Bala and Alpa Ayu and are more susceptible to illnesses. Pitta Prakriti people have Madhyama Bala and Madhyama Ayu and are moderately prone to diseases, whereas Kapha Prakriti people have Uttama Bala and Uttama Ayu and are moderately prone to diseases. Prakriti, Vikara, Kala, and Bala are all linked to sustaining human health and producing sickness. Different illnesses result when Doshas rise or decrease in a person during specific seasons. Adana Kala and Visarga Kala are the two divisions of Kala. The debilitating phase is known as Adana Kala. The sun depletes one's physical power. The moon is powerful in Visarga Kala, and it provides strength to the living organism. These changes in the environment cause changes in the body's Dosha sthiti. Ritucharya (seasonal lifestyle) is recommended by Ayurveda for preventing illnesses caused by changes in Tridosha owing to Kala (season). In this study, we attempted to promote Ritucharya about Prakriti.
\end{abstract}

Keywords: Ayurveda, Ritucharya, Prakriti, Tridosha, Ritu 


\section{INTRODUCTION}

Every man and woman on the planet is born with physical and mental characteristics that will follow them throughout their lives. Prakriti is characteristics that are necessary by birth. Growing persons can be distinguished with these distinct types of Doshika Prakriti $^{(1)}$.

Ayurveda is a life science ${ }^{(2)}$. The main goal of Ayurveda is not only to treat ailments but also to protect people from all kinds of life's problems and diseases. The body (Sharir), senses (Indriyas), intellect (Satwa), and spirit (Atma) are all intertwined in life ${ }^{(3)}$. In Ayurveda, the soul and five fundamental entities termed Panchamahabhutas (five fundamental entities) are primarily regarded in the formation of living beings ${ }^{(4)}$. The Panchamahabhutas (five basic beings) are responsible for the creation of the entire physical world through their unique combinations. As a result, the human body is made up of five Mahabhutas (fundamental entities). The exterior atmosphere is controlled by a variety of external environmental forces such as the Sun, Moon, and Air, among others. The same forces have numerous direct and indirect impacts on the human body.

Because of differences in genetic makeup, which is regulated by Tridoshas, the effects noticed on diverse individuals are not the same. The Panchamahabhutas (five fundamental entities) or the aim of physiological processes are considered to be the primary constituents of the body. They are in charge of the human body's integrity and oversee the entire system. When external influences vitiate these Tridoshas, numerous forms of somatic problems emerge, leading to illnesses ${ }^{(5)}$.

Thus, an individual's health is determined by the natural position of Dosha, Dhatu, and $\mathrm{Mala}^{(6)}$. Ayurveda suggested particular lifestyle regimens for longevity and health, such as Dincharya (daily lifestyle), Ritucharya (seasonal lifestyle) etc.

The Ritucharya (season cycle) has six Ritus (characters), each of which is responsible for increasing the same characteristics in nature and humans while depressing the opposite attributes ${ }^{(7)}$. This is why human beings have Chaya, Prakopa, and Prashama of Tridoshas in corresponding Ritus ${ }^{(8)}$. The quality of this Tridoshas variation varies from person to person.

If the Doshas (genetic constitution) match the naturally vitiated Doshas in the body, the chances of vitiation of Doshas in that Prakriti (genetic constitution) are higher. For example, in Vasanta ritu kala (spring), nature favours Kapha prakopa owing to the sun's heat. With even the tiniest Kaphaja aharaVihara, those with Kaphaja Prakriti will surely exhibit indications of Kapha prakopa. Thus, research into these impacts in all six Ritus (seasons) and diverse Prakrities (genetic constitutions) would aid in the prevention and healing of vitiated Tridoshas and, as a result, further diseases.

Because the fertilisation of the ovum is also dependent on time, the season plays a significant influence on the genetic composition. "After the Rajo darshana (menstrual cycle) has ended, the 12 nights are solely beneficial for fertilisation," Sushruta remarked. The mature ovum is released through one of the two ovaries on or around the 14th day of the cycle, according to current physiology, therefore the period around the 14th day is optimal for certain conception. This depicts the relationship between Kala (season) and Prakriti (genetic constitution) from the beginning to the end of one's life.

\section{AIM \& OBJECTIVES}

- To evaluate the Deha prakriti of the volunteers under study.

- To re-evaluate, discuss, and elaborate the Ayurvedic concept of Ritucharya in different Samhitas.

- To evaluate the relation between Deha prakriti and Ritucharya.

\section{MATERIALS \& METHODS}

This article is based on a review of Ayurvedic texts. Materials related to Prakriti, Ritucharya and other relevant topics have been collected. The main Ayurvedic texts used in this study are Charaka Samhitha, Sushruta Samhita, Astanga Hridaya and available commentaries on these texts. We have also referred to the various websites and scientific journals 
to collect information regarding current research on the relevant topics.

\section{RELATIONSHIP WITH RITU}

Doshas (vata pitta kapha) are the pillars of the physical body, and they must be in a balanced state both within themselves and with their surroundings, for which Ritucharya, as indicated in ancient Ayurvedic literature, plays a significant role. Summer is a time for renewal, whilst winter is a time for hibernating. When the external environment is hot, as it is in the summer, Tejas is used extensively, resulting in an excess of Pitta. When the external environment is chilly, hibernation and ojas stability are required, and an excess of either causes Kapha imbalance. The somatic humour or doshas conditions alter as one ritu changes.

\section{EFFECT OF RITU ON TRIDOSHA}

Ayurveda is a system of medicine that has been practised for thousands of years. The Tridoshas (Vata, Pitta, and Kapha) are the body's functioning triads. These doshas are in charge of the origin, development, and upkeep of the human body in its natural state. They become the primary cause of human body destruction when they are in an abnormal state. The normal status of tridoshas is affected by seasonal variations. Vata, pitta, and kapha accumulate, vitiate, and pacify at different times of the year..$^{(9,10,11)}$

Table 1: Relation between Ritu and Doshas

\begin{tabular}{|l|l|l|l|}
\hline Doshas & SANCHAYA & PRAKOPA & PRASHAMANA \\
\hline Vata & Greeshma & Varsha & Sharad \\
\hline Pitta & Varsha & Sharad & Hemanta \\
\hline Kapha & Hemanta & Basanta & Greeshma \\
\hline
\end{tabular}

\section{EFFECT OF RITU ON BALA}

The bodily vigour of men is lowest at the beginning and end of the sun's period of release and absorption, respectively; it is moderate in the middle of these periods, and it is widely known that the bodily vigour is strongest after the former and beginning of the latter period. ${ }^{(12)}$

Table 2: Relation with Ritu and Doshas

\begin{tabular}{|l|l|l|l|l|}
\hline Ayana & Ritu & Month & Hindi month & Bala \\
\hline & Shishira & Jan-Feb & Magha-Falguna & Uttama \\
\hline Uttarayana Or Adana Kala & Vasanta & Mar-April & Chaitra-Vaishakh & Madhyama \\
\hline & Grishma & May-June & Jyeshtha-Ashadha & Heena \\
\hline Dakshinayana Or Visharga Kala & Varsha & July-Aug & Sravan-Bhadrapada & Heena \\
\hline & Sharada & Sep-Oct & Ashwina-Kartika & Madhyama \\
\hline & Hemanta & Nov-Dec & Margashisha-Pausha & Uttama \\
\hline
\end{tabular}

Effect Of Ritu On Rasa: Each season is made up of two months, dividing the year into six seasons. These divides were meant to represent the typical state of rasas and their origin. Based on the predominance of the sun and moon's effects, this six ritu are separated into two ayana, Dakshinayan and Uttarayana. Moon is prevalent during dakshinayana (Varsha, Sharad, Hemanta), hence Amla, Lavana, and Madhur rasa are more intense. Because the Sun is more powerful during Uttarayana (Shishira, Vasanta, and Grishma), Tikta, Kashaya, and Katu rasa are more powerful. ${ }^{(13)}$ 
Table 3: Relation between Ritu and Shdarasa

\begin{tabular}{|l|l|}
\hline Ritu & Predominant Rasa \\
\hline Shishira & Tikta(Bitter) \\
\hline Vasanta & Kashaya(Astringent) \\
\hline Grishma & Katu(Pungent) \\
\hline Varsha & Amla(Sour) \\
\hline Sharada & Lavana(Salt) \\
\hline Hemanta & Madhur (Sweet) \\
\hline
\end{tabular}

Effect Of Ritu On Agni: The Agni of a person will be weak at the beginning and end of the Visharga and Adana periods, according to ayurveda. Agni will be moderate at the middle of adana kala and the middle of visharga kala. Individual agni will be at its best towards the conclusion and beginning of the day.

Table 4: Relation between Ritu and Agni

\begin{tabular}{|l|l|}
\hline Ritu & Agni \\
\hline Shishira & Teekshnagni \\
\hline Vasanta & Madhyamagni \\
\hline Grishma & Mandagni \\
\hline Varsha & Mandagni \\
\hline Sharada & Madhyamagni \\
\hline Hemanta & Teekshnagni \\
\hline
\end{tabular}

The Ahara, Desha, Jala, Vayu and Kala (time) are the factors that are common and responsible for atmospheric changes. The excess or deficient or false manifestation or Ritu kala (season) are going to affect the Prakriti and so one must follow the specific Ritucharya (seasonal lifestyle).

\section{Hemanta Ritucharya}

In Hemanta Ritu, the atmosphere is extremely cold, so the air, water, and other topics become frigid. The days are shorter than the nights. The skin is affected by the cold. The blood arteries contract to prevent the body from losing heat. As a result, the internal body heat rises, causing the Agni to rise, resulting in increased appetite, digestion, and hence body strength and power. The man becomes hungry early in the morning as the evenings grow longer. So, in Hemanta, one should eat food comprising Madhura, Amla, Lavana rasas and Guru, Snigdha diet in the morning; otherwise, the Vata Dosha is more likely to increase. (14)

\section{Shishira Ritucharya}

In general, the Shishira Ritu (winter) environment is identical to that of Hemanta (fall-winter). The only difference is that the Adana Kala starts with Shishira, therefore the Ruksha guna is heightened owing to the cold. To avoid Kapha-chaya, a Kapha Prakriti person should not perform Kaphaja Ahara and Vihara in Shishira Ritu. In his diet, he must have Katu, Tikta, and Kashaya rasas. The Pittaja individual should act by the body's needs as the environment changes.

\section{Vasanta Ritucharya}

Due to the natural beauty of the surroundings, this ritu is said to be the most attractive. Beautiful flowers, fruits, and green leaves can be found throughout nature. These alterations are particularly noticeable in Kapha Prakriti people. During this time, the Drava guna of Kapha increases, resulting in a loss of appetite and poor digestion (Agnimandya). As a result, this season is mostly for the Kapha dosha, which should be managed by Ritu charya.

\section{Grishma Ritucharya}

Because the Sun is closer to the Prithvi during this season, the rays are shorter and sharper, resulting in additional heat. There is a significant loss of perspiration, energy, and power. After even light work, a person becomes easily weary. The Kapha 
dosha diminishes while the Vata dosha grows. Katu rasa occurs when the atmosphere gets exceedingly sluggish and dry. The Ushna and Tikshna gunas have a greater impact on Pitta Prakriti people.

\section{Varsha Ritucharya}

Varsha Ritu has a gloomy atmosphere, and the sky is foggy. The strength and potency of Adana Kala are reduced. The damp and overcast weather impair one's appetite and digestion. As a result, the cloudy weather is to blame for the increase in Vata caused by Shita guna. The new rainwater is fresh, chilly and muddy just like Amla Vipaki, which is why Pitta dosha is accumulating. As a result, the risk of disease increases during this season, and one must maintain a healthy Agni.

\section{Sharada Ritucharya}

The Sun is extremely hot, the atmosphere is also extremely hot and permeable. The night is clear and cool in some way. The scorching and penetrating Sun aggravates the Pitta dosha, leading to Pitta Prakopa in the Varsha Ritu. Pitta dosha likewise vitiates the blood because both have the same capacities. Due to vitiated Pitta dosha, the Agni is also insufficient (Agnimandya).

\section{DISCUSSION}

Since 1500 B.C., Ayurveda has been documented and practised in India as an ancient system of customised medicine. According to the above-mentioned literature, the sun, wind, and moon are responsible for the emergence of time, season, rasa, dosha, and physiological strength, respectively, depending on the nature and course of time they follow. The forces and energies of the two seasons (Dakshinayan and Utaarayana) are diametrically opposed. Individuals' strength, digestive power, and taste are all affected by seasonal fluctuations. We can prevent the emergence of various diseases and maintain our health by following suitable Aahara and Vihaar according to the season. Prakriti is the body's underlying genetic makeup. Prakriti is a term used in Ayurveda to define seven different types of constitution. According to Acharya Charaka Sukra-Shonita Prakriti, KalaGarbhasaya Prakriti, Maturaharavihara Prakriti, and
Panchamahabhuta-vikara Prakriti are four variables that influence Prakriti determination ${ }^{(15)}$. The Kala has a special effect on the Dosha that is prevalent during Prakriti development. Individuals with different Prakriti have different sensitivities to the six Kala ${ }^{(16)}$. Prakriti is influenced by a variety of circumstances, one of which is the timing of conception. According to Acharya Charak ${ }^{(17)}$, Sushruta ${ }^{(18)}$, and Vagbhata ${ }^{(19)}$ Vata, Pitta, and Kapha Prakopa occur in Varsha, Sharad, and Vasanta Ritu.

\section{CONCLUSION}

Prakriti is the body's fundamental genetic background. The Kala has a strong influence on the Doshas that are prevalent during Prakriti development. Individuals from various Prakrities also have distinct sensitivities to six Ritu Kalas. The physiological changes are more noticeable than the physical ones. In different Ritus, one must practise Ritucharya according to Prakriti, e.g. Varsha ritucharya for Vataj prakriti, Sharad ritucharya for Pittaj prakriti, and Vasant ritucharya for Kaphaja prakriti, depending on climatic conditions.

Ritucharya should be practised according to Dosha state in other Ritus. Panchakarma is used to cleanse the body owing to various stages of Doshas, such as Chaya, Prakopa, and Prasara. As a result, Kala is a significant contributory component in many changes in both nature and the human body.

\section{REFERENCES}

1. Agnivesha. Charaka Samhita, English translation by Sharma RK, Dash B. Viman-Sthan, Chaukhambha Sanskrit series office, Varanasi. 2010; 2:8-95.

2. Dr Brahmanand Tripathi. Charak Samhita. 7th Edition (Sutrasthana Chp. 1-41). Varanasi, Chaukhamba Surbharti Prakashan, 2000. p.13.

3. Dr Brahmanand Tripathi. Charak Samhita. 7th Edition (Sutrasthana Chp. 1-42). Varanasi, Chaukhamba Surbharti Prakashan, 2000. p.14.

4. Dr Brahmanand Tripathi. Charak Samhita. 7th Edition (Sharirasthana Chp. 1-16). Varanasi, Chaukhamba Surbharti Prakashan, 2000. p. 791.

5. Kaviraja Atrideva Gupta. Ashtanga Hridayam. 13th Edition. (Sutrasthana Chp. 1-19). Varanasi, Chaukhamba Sanskrit Sansthan, 2000. p. 10. 
6. Kaviraja Ambikadutta Shashtri. Sushruta Samhita. 12th Edition. (Sutrasthana Chp. 15- 48). Varanasi, Chaukhamba Sanskrit Sansthan, 2001.p. 64.

7. Dr Brahmanand Tripathi. Charak Samhita. 7th Edition (Sutrasthana Chp. 1-45). Varanasi, Chaukhamba Surbharti Prakashan, 2000. p.16.

8. Kaviraja Atrideva Gupta. Ashtanga Hridayam. 13th Edition. (Sutrasthana Chp. 12-24/25). Varanasi, Chaukhamba Sanskrit Sansthan, 2000. p. 92

9. Agnivesh, Charak Sutra 17/114, In K R Srikantha Murthy Charak Samhita (textbook with English translation) Vol I, reprint edition, Varanasi, Chaukhambha Orientalia 2009

10. Sushruta, Sushruta Sutra 6/12,13, In Sharma PV. Sushruta Samhita (with the English translation of text and Dalhan's commentary along with critical notes) Vol I, Reprint edition, Varanasi, Chaukhambha Visvabharti 2005.

11. Vagbhata, Ashtanga Sangraha Sutra 21/9-13, In K R Shrikantha Murthy, Ashtanga Sangraha of (textbook with English translation) Vol I, Third edition, Varanasi

12. Agnivesh, Charak Sutra 6/8, In K R Srikantha Murthy Charak Samhita (textbook with English translation) Vol I, reprint edition, Varanasi, Chaukhambha Orientalia 2009.

13. Sushruta, Sushruta Sutra 6/7, In Sharma PV. Sushruta Samhita (with the English translation of text and Dalhan's commentary along with critical notes) Vol I, Reprint edition, Varanasi, Chaukhambha Visvabharti 2005.

14. Dr Brahmanand Tripathi. Charak Samhita. 7th Edition (Sutrasthana Chp. 6-10). Varanasi, Chaukhamba Surbharti Prakashan, 2000. p.150.

15. Agnivesha. Charaka samhita, English translation by Sharma RK, Dash B. Viman Sthan Chaukhambha Sanskrit series office, Varanasi. 2010; 1(8):95.

16. Bakal Nilesh Ganeshrao, Lode Dattatraya Somaji, Patil Aparna Shrikrishna. Ritu (Season), Ritucharya and Prakriti- A Conceptual Study. Int. J Ayur. Pharma Research. 2014; 2(2):101-110

17. Agnivesha. Charaka samhita, English translation by Sharma RK, Dash B. Sutra Sthan Chaukhambha Sanskrit series office, Varanasi. 2010; 1(17):114.

18. Sushruta. Sushruta samhita, English translation by Sharma P.V, Sutra-sthan, Chaukhambha Vishvabharati, Varanasi. 2005; 1(6)12-13.

19. Vagbhata. Astanga samgraha, English translation by Srikantha Murty KR, Sutra sthana, Chaukhambha Orientalia, Varanasi. 2001 1(21):9.

\section{Support: Nil Conflict of Interest: None Declared}

How to cite this URL: Savita \& Ashok Kumar Sharma: Correlation Between Prakriti And Ritucharya: A Conceptual Study. International Ayurvedic Medical Journal \{online\} 2021 \{cited July 2021\} Available from: http://www.iamj.in/posts/images/upload/1495_1500.pdf 